\title{
Shelter/housing options, supports and interventions for older people experiencing homelessness
}

\author{
Sarah L. Canham ${ }^{1,2 *}$ (D) Joe Humphries ${ }^{3}$, Piper Moore ${ }^{1}$, Victoria Burns ${ }^{4}$ and Atiya Mahmood ${ }^{3}$ \\ ${ }^{1}$ College of Social Work, University of Utah, Salt Lake City, Utah, USA, ${ }^{2}$ College of Architecture and \\ Planning, University of Utah, Salt Lake City, Utah, USA, ${ }^{3}$ Department of Gerontology, Simon Fraser \\ University, Vancouver, Canada and ${ }^{4}$ Faculty of Social Work, University of Calgary, Calgary, Canada \\ ${ }^{*}$ Corresponding author. Email: sarah.canham@utah.edu
}

(Accepted 2 February 2021; first published online 25 March 2021)

\begin{abstract}
While experiences of later-life homelessness are known to vary, classification of shelter, housing and service models that meet the diverse needs of older people with experiences of homelessness (OPEH) are limited. To address this gap, a scoping review was conducted of shelter/housing options, supports and interventions for OPEH. Fourteen databases were searched for English-language peer-reviewed and/or empirical literature published between 1999 and 2019, resulting in the inclusion of 22 sources. Through a collaborative, iterative process of reading, discussing and coding, data extracted from the studies were organised into six models: (1) long-term care, (2) permanent supportive housing (PSH), including PSH delivered through Housing First, (3) supported housing, (4) transitional housing, (5) emergency shelter settings with health and social supports, and (6) case management and outreach. Programme descriptions and OPEH outcomes are described and contribute to our understanding that multiple shelter/housing options are needed to support diverse OPEH. The categorised models are considered alongside existing 'ageing in place' research, which largely focuses on older adults who are housed. Through extending discussions of ageing in the 'right' place to diverse OPEH, additional considerations are offered. Future research should explore distinct sub-populations of OPEH and how individual-level supports for ageing in place must attend to mezzoand macro-level systems and policies.
\end{abstract}

Keywords: homelessness; supportive housing; support services; emergency shelter; scoping review

\section{Introduction}

Older people with experiences of homelessness (OPEH) remain largely invisible in research, policy and practice domains though rates of this population are increasing (Crane and Warnes, 2010; Gonyea et al., 2010; Culhane et al., 2019). OPEH include people aged 50+ who have experienced chronic/episodic homelessness or are

(c) The Author(s), 2021. Published by Cambridge University Press. This is an Open Access article, distributed under the terms of the Creative Commons Attribution licence (http://creativecommons.org/licenses/by/4.0/), which permits unrestricted re-use, distribution, and reproduction in any medium, provided the original work is properly cited. 
experiencing homelessness for the first time in later life, both of which are associated with accelerated ageing that predisposes younger-aged people to geriatric health conditions normally associated with old age (Brown et al., 2013a). For instance, OPEH are at risk of exposure, infectious disease, injury, trauma, stress and violence, and have limited options to participate in healthy lifestyles, resulting in negative health and psycho-social outcomes (Khandor and Mason, 2007; Homeless Link, 2014). In this study, homelessness is defined as being (a) unsheltered or absolutely homeless and living on the streets or in places not intended for human habitation; (b) emergency sheltered, including staying in homeless or family violence shelters; (c) provisionally accommodated, including living temporarily with others, couch surfing or in institutional settings; or (d) at-risk of homelessness, including living in precarious or substandard housing (Gaetz et al., 2016).

Compared to younger people experiencing homelessness, and older adults in general, OPEH have more complex health and social challenges and significant unmet needs regarding access to suitable shelter/housing and support services (McDonald et al., 2007, 2009; McGhie et al., 2013). For example, functional impairments and chronic health conditions, including difficulties with activities of daily living (e.g. eating, bathing) and instrumental activities of daily living (e.g. financial and medication management) (Brown et al., 2017), as well as depression, anxiety, post-traumatic stress disorder, psychosis and cognitive impairment of OPEH (Stergiopoulos and Herrmann, 2003; Garibaldi et al., 2005; Sudore et al., 2018), are challenging to support in traditional shelter/housing settings (Canham et al., 2020). Yet, there are few shelter/ housing options to support the diverse physical, mental and social needs of OPEH (Serge and Gnaedinger, 2003). Furthermore, homelessness programming largely targets youth and people who have experienced chronic homelessness rather than OPEH (Canham et al., 2018), thus, there is a research, policy and practice need to identify and describe shelter/housing models and outcomes for OPEH.

'Ageing in place' research, policy and practice goals are based on the assumption that individuals have access to stable housing (Bigonnesse and Chaudhury, 2002; Means, 2007; Pani-Harreman et al., 2021). As limited research suggests, this can lead to OPEH feeling 'stuck in place' or 'oscillating in and out of place' rather than ageing in place (Torres-Gil and Hofland, 2012; Burns, 2016). Despite there being few options that address the diverse needs of OPEH or enable them to age in place (Furlotte et al., 2012; McLeod and Walsh, 2014; Burns, 2016; Canham et al., 2018, 2020; Burns and Sussman, 2019), a growing body of literature recognises that innovation is required to support ageing in the right place for marginalised older adults (e.g. McGhie et al., 2013; Sixsmith et al., 2017; Humphries and Canham, 2019).

Humphries and Canham (2019) have developed a conceptual model of how different trajectories into homelessness (e.g. chronic/episodic versus first time in late life) give rise to unique needs and solutions to support ageing in the right place for OPEH. While this model identified three broad types of shelter/housing for OPEH (i.e. Housing First, permanent supportive housing and multi-service homelessness intervention programmes), Humphries and Canham (2019) did not provide a detailed description of different shelter/housing options. The review by McGhie et al. (2013) identified affordable housing, supported and supportive housing, emergency shelter/housing and long-term care as models for OPEH, however, their literature review was limited to options in Canada only. With unique political and social 
landscapes across different countries, there is a range of shelter/housing options, supports and interventions for OPEH which have not been captured in earlier reviews that were limited in scope or geography. The purpose of this study is to identify and describe shelter/housing options, supports and interventions (i.e. models) for $\mathrm{OPEH}$, as well as reported outcomes. Our guiding research question is:

- What shelter/housing options, supports and interventions have been developed for older people (age 50+) who are currently or formerly experiencing homelessness?

We subsequently ask:

- What are the reported outcomes of these shelter/housing options, supports and interventions?

\section{Methods}

We used a scoping review methodology based on Arksey and O'Malley (2005), which enables researchers to capture rigorously and transparently the nature and breadth of the literature without assessing the quality of evidence. We also drew from the recommendations for conducting scoping reviews of Levac et al. (2010) by establishing welldefined inclusion and exclusion criteria (step 1), and using these criteria and the research question to identify relevant studies (step 2). We then selected studies (step 3) in an iterative process whereby authors $\mathrm{JH}$ and $\mathrm{PM}$ independently reviewed titles and abstracts for inclusion, meeting weekly with author SC to discuss process and progress, and using Covidence software (https://www.covidence.org) to assist in the organisation of relevant and selected studies. During weekly meetings, discrepancies in authors' inclusion decisions were discussed by the three authors until a final determination was made. Studies that met the following criteria were included: (a) described a shelter/housing option, support or intervention for OPEH (age 50+ and currently or formerly experiencing homelessness - absolutely homeless, residing in a place unsuitable for habitation, a shelter or transitional housing, or at-risk of homelessness); (b) presented primary empirical data; and (c) available in the English language. Both peer-reviewed and grey literature were included if primary empirical data were presented, while literature reviews and policy reviews were excluded if no primary data were presented. Additionally, a hand search of articles in the bibliographies of these documents was conducted to identify relevant studies. Next, using Excel as an organisational tool, the research team developed a data-charting form, which included study location, study design, participant characteristics, a description of the model and main findings, and JH and PM independently extracted and charted data (step 4). Finally, results were summarised and collated (step 5), enabling the research team to report results relevant to the study's research question (Levac et al., 2010).

\section{Study selection}

To establish an effective search strategy (Levac et al., 2010), SC consulted with a university librarian to develop a study protocol and to determine specific search databases 
Table 1. Databases, search terms and search strings

\begin{tabular}{|c|c|c|c|}
\hline Database(s) & \multicolumn{3}{|c|}{ Search terms and search strings } \\
\hline \multirow{6}{*}{$\begin{array}{l}\text { Academic Search } \\
\text { Premier, Ageline, } \\
\text { CINAHL Complete, } \\
\text { ERIC, Global Health, } \\
\text { Medline with Full Text, } \\
\text { Project Muse, ProQuest } \\
\text { Sociology Collection, } \\
\text { PsycINFO, Social } \\
\text { Sciences with Full Text, } \\
\text { Social Work Abstracts }\end{array}$} & \multirow{6}{*}{$\begin{array}{l}\text { homeless }{ }^{\star} \text { OR } \\
\text { housing } \\
\text { insecurity OR } \\
\text { housing security } \\
\text { OR vulnerable } \\
\text { OR at-risk }\end{array}$} & \multirow{6}{*}{$\begin{array}{l}\text { older adult* OR } \\
\text { senior* OR older } \\
\text { person* OR elder* } \\
\text { OR aging OR } \\
\text { ageing OR } \\
\text { age-related OR late } \\
\text { life OR later life }\end{array}$} & hostel OR shelter \\
\hline & & & $\begin{array}{l}\text { aging in place OR } \\
\text { ageing in place }\end{array}$ \\
\hline & & & $\begin{array}{l}\text { supportive housing } \\
\text { OR supported } \\
\text { housing OR housing } \\
\text { supports OR assisted } \\
\text { living }\end{array}$ \\
\hline & & & $\begin{array}{l}\text { housing OR } \\
\text { accommodation OR } \\
\text { independent living }\end{array}$ \\
\hline & & & housing first \\
\hline & & & $\begin{array}{l}\text { respite OR } \\
\text { convalescence OR } \\
\text { medical stabilization }\end{array}$ \\
\hline Web of Science ${ }^{2}$ & \multicolumn{3}{|c|}{$\begin{array}{l}\text { (ti:((homeless* OR housing insecurity OR housing security OR } \\
\text { vulnerable OR at-risk) AND (older adult* OR senior* OR older person* } \\
\text { OR elder* OR aging OR ageing OR age-related OR late life OR later life) } \\
\text { AND (hostel OR shelter OR aging in place OR ageing in place OR } \\
\text { supportive housing OR supported housing OR housing supports OR } \\
\text { assisted living OR housing OR accommodation OR independent living } \\
\text { OR respite OR convalescence OR medical stabilization OR housing } \\
\text { first))) }\end{array}$} \\
\hline Geobase $^{1}$ & \multicolumn{3}{|c|}{ homeless* AND older* AND (housing OR shelter) } \\
\hline Google Scholar ${ }^{2}$ & \multicolumn{3}{|c|}{$\begin{array}{l}\text { Title searches for combination of: } \\
\text { older OR aging OR ageing OR late life OR later life OR age-related OR } \\
\text { senior OR seniors OR elder OR elders } \\
\text { homeless OR homelessness } \\
\text { housing OR shelter OR accommodation OR respite OR convalescence } \\
\text { OR medical respite }\end{array}$} \\
\hline JSTOR $^{1}$ & \multicolumn{3}{|c|}{$\begin{array}{l}\text { ((ti:older adult* OR senior* OR older person* OR elder* OR aging OR } \\
\text { ageing OR age-related OR late life OR later life) OR (ab:older adult* OR } \\
\text { senior }{ }^{\star} \text { OR older person* OR elder* OR aging)) AND (ti:homeless* OR } \\
\left.\text { ab:homeless }{ }^{\star}\right)\end{array}$} \\
\hline
\end{tabular}

Notes: ab: abstract. ti: title. 1. Both title and abstract searched in these databases. 2 . Only title searched in these databases.

and criteria, including search terms and strings that would enable the capture of available literature within range (sensitivity) and relevance (specificity). From 24 August 2019 to 15 October 2019, JH and PM searched 15 databases (Academic Search Premier; Ageline; CINAHL Complete; ERIC; Geobase; Global Health; Google Scholar; JSTOR; Medline with Full Text; ProQuest Sociology Collection; Project Muse; PsycINFO; Social Sciences with Full Text; Social Work Abstracts; and Web of Science) for English-language peer-reviewed and/or empirical literature published from 1999 to 2019. Keyword searches included various combinations of terms, including homeless, at-risk, older adult, senior, aging/ageing, shelter, housing, accommodation, respite, etc. (Table 1). Results revealed 6,734 references, of which 3,944 


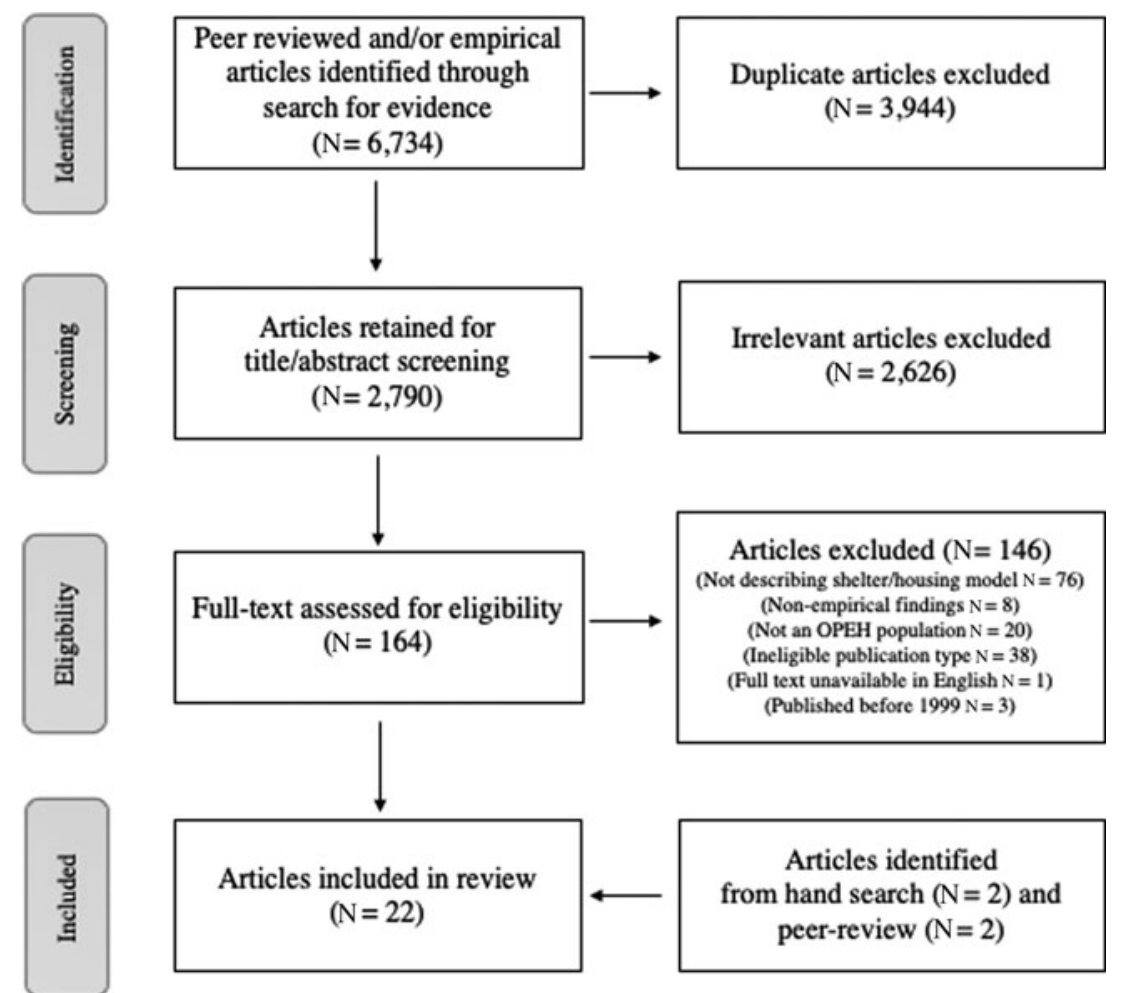

Figure 1. PRISMA flow diagram of literature inclusion. Note: OPEH: older people with experiences of homelessness.

duplicates were removed (for the PRISMA flow diagram, see Figure 1). Titles and abstracts of 2,790 articles were assessed for inclusion by JH and PM, and through discussion with SC any discrepancies in article inclusion were resolved, resulting in 164 articles for full-text review. During the full-text review, if a text described empirical findings, a hand-search of that text's bibliography was conducted to identify any literature not previously captured.

During study selection, studies were excluded for not describing a model $(\mathrm{N}=76)$; reporting non-empirical programme descriptions or findings from a literature review or policy review $(\mathrm{N}=8)$ or on a population other than OPEH $(\mathrm{N}=20)$; and being the wrong publication type $(\mathrm{N}=38)$, unavailable in English $(\mathrm{N}=1)$ or published prior to $1999(\mathrm{~N}=3)$. After screening, 18 articles remained; additional sources that met criteria for inclusion were identified through the hand-search $(\mathrm{N}=2)$ and following peer-review $(\mathrm{N}=2)$, resulting in a total of 22 articles included in the review.

The sources that reported research data used mixed $(\mathrm{N}=8)$, qualitative $(\mathrm{N}=7)$ and quantitative $(\mathrm{N}=5)$ methods, while two sources reported conducting surveys but did not indicate if they were mixed methods or quantitative. Fifteen of the studies collected data from OPEH, two from service providers, and five from both service providers and OPEH. Sixteen sources were peer-reviewed articles, one was a non-peer-reviewed article and five were reports. Sources 
Table 2. Literature sources, study characteristics, description of shelter/housing model and main findings

\begin{tabular}{|c|c|c|c|c|c|}
\hline Author (year) Title & $\begin{array}{l}\text { Publication } \\
\text { type (journal) }\end{array}$ & Country & $\begin{array}{l}\text { Study design and } \\
\text { participants }\end{array}$ & Description of shelter/housing model & Main findings \\
\hline \multicolumn{6}{|l|}{ Long-term care: } \\
\hline $\begin{array}{l}\text { Rota-Bartelink (2016) } \\
\text { Wicking Project II: The } \\
\text { Provision of Skilled } \\
\text { Specialist Consultancy } \\
\text { Services to People Living } \\
\text { with Highly Complex Needs } \\
\text { and Their Caregivers }\end{array}$ & $\begin{array}{l}\text { Report } \\
\text { (Wintringham) }\end{array}$ & Australia & $\begin{array}{l}\text { Mixed methods. } \\
\text { Two trials with } 14 \\
\text { (Wicking I) and } 15 \\
\text { (Wicking II) OPEH } \\
\text { aged } 50+\text { with } \\
\text { dementia } \\
\text { resulting from } \\
\text { alcohol-related } \\
\text { acquired brain } \\
\text { injury }\end{array}$ & $\begin{array}{l}\text { - Wintringham's Wicking Project I and II } \\
\text { (Melbourne, Australia) } \\
\text { - Wicking Project I is a four-bedroom } \\
\text { community home providing residential } \\
\text { care } \\
\text { - Wicking Project II is a } 60 \text {-bed residential } \\
\text { care facility with individual bedrooms } \\
\text { and common areas } \\
\text { - 24-hour care support with intensive } \\
\text { individualised, specialised case } \\
\text { management and recreational support }\end{array}$ & $\begin{array}{l}\text { - Compared to controls, Wicking Project } \\
\text { participants had improved life quality and } \\
\text { mental health indicators per person per day } \\
\text { cost-to-government savings } \\
\text { - Helped participants reduce the frequency } \\
\text { and impact of challenging behaviours, } \\
\text { improved health and wellbeing, and } \\
\text { decreased levels of hospitalisation and crisis } \\
\text { and criminal justice service usage }\end{array}$ \\
\hline $\begin{array}{l}\text { Serge and Gnaedinger } \\
\text { (2003) Housing Options for } \\
\text { Elderly or Chronically III } \\
\text { Shelter Users }\end{array}$ & $\begin{array}{l}\text { Report } \\
\text { (Canada } \\
\text { Mortgage and } \\
\text { Housing } \\
\text { Corporation) }\end{array}$ & Canada & $\begin{array}{l}\text { Qualitative. } \\
\text { Case studies of } 13 \\
\text { housing models } \\
\text { and supports; } \\
\text { interviews with } 20 \\
\text { service providers }\end{array}$ & $\begin{array}{l}\text { - Former Integrated Program, Oak Bay } \\
\text { Lodge (Victoria, Canada) } \\
\text { - Three beds in a 282-bed LTC facility were } \\
\text { designated for clients of an outreach } \\
\text { programme that serves older adults with } \\
\text { difficulties with substance use, including } \\
\text { some who are cyclically homeless } \\
\text { - Clients of the Integrated Program had } \\
\text { access to all supports available in the } \\
\text { LTC facility, including 24-hour nursing } \\
\text { and three meals a day, and were } \\
\text { supported by a designated outreach } \\
\text { worker } \\
\text { - Programme discontinued in } 2002\end{array}$ & $\begin{array}{l}\text { - Participants reported that LTC is often } \\
\text { unprepared to cope with complex needs of } \\
\text { OPEH; alcohol use, in particular, can be } \\
\text { challenging } \\
\text { - OPEH face many barriers to accessing LTC, } \\
\text { including participating in eligibility } \\
\text { assessments while living in shelters/on the } \\
\text { streets } \\
\text { - Service provider interviews suggest both } \\
\text { integration into mainstream facilities and } \\
\text { segregated models (for OPEH only) should } \\
\text { be made available }\end{array}$ \\
\hline \multicolumn{6}{|c|}{ Permanent supportive housing (PSH): } \\
\hline $\begin{array}{l}\text { Brown et al. }(2013 \mathrm{~b}) \\
\text { Meeting the housing and } \\
\text { care needs of older } \\
\text { homeless adults: a } \\
\text { permanent supportive } \\
\text { housing program targeting } \\
\text { homeless seniors }\end{array}$ & $\begin{array}{l}\text { Peer-reviewed } \\
\text { article } \\
\text { (Seniors } \\
\text { Housing \& Care } \\
\text { Journal) }\end{array}$ & USA & $\begin{array}{l}\text { Qualitative. } \\
\text { Describes three } \\
\text { case studies of } \\
\text { OPEH aged } 60+\end{array}$ & $\begin{array}{l}\text { - HEARTH (Boston, USA) } \\
\text { - } 196 \text { wheelchair-accessible units in eight } \\
\text { buildings with group meals and } \\
\text { activities to nurture a sense of } \\
\text { community } \\
\text { - Outreach programme helps clients apply } \\
\text { for other available subsidised housing }\end{array}$ & $\begin{array}{l}\text { Case studies highlighted that outreach, } \\
\text { subsidised housing and supportive services } \\
\text { have an important role in OPEH securing } \\
\text { and maintaining permanent housing }\end{array}$ \\
\hline
\end{tabular}


Gibeau (2001) Home free: an evolving journey in eradicating elde

homelessness
Peer-reviewed

article

(Topics in

Geriatric

Rehabilitation
USA

\section{Qualitative.}

Interviews and

focus groups with

30 service

providers and 63

OPEH aged $45+$

\section{Report \\ (Canada \\ Mortgage and \\ Housing \\ Canada \\ Mixed methods. \\ Case study of 30 \\ OPEH aged $45+$ \\ and eight service}

Corporation providers

- Provides case management to assist with housing applications, system

navigation, financial security, social

assistance, health-care co-ordination

and transportation

Woods, Final Report

- Committee to End Elder Homelessness (now HEARTH; Boston, USA)

- Provides outreach, case management and PSH in multiple sites

- Provides community building and health promotion programmes, case management and on-site personal care services

- Fairway Woods (Victoria, Canada)

- 32 self-contained one-bedroom

apartments with communal dining room, lounges, balconies, library,

kitchen and garden

- 24-hour staffing, site visits from community health and one meal per day Designed for tenants with a median age diagnoses, including physical and mental health conditions and addictions of 55-64 who have multiple complex

- Service providers identified that mental health and alcohol use were the most common client issues and that the most important steps to obtaining housing were building trust and medical stabilisation

- Client desire to stay in the shelter was reported as a barrier to rehousing

- $52 \%$ of surveyed tenants self-rated quality of life as good; $52 \%$ rated their physical health as good/excellent; $87 \%$ rated their mood as fair/good/excellent; and $74 \%$ rated their living situation as good/excellent

- Surveyed tenants valued the quiet, suburban setting, the predictability of everyday life, the proximity of shops and services, the social aspects of living at Fairway Woods and the provision of 24-hour on-site staff - Provides health assessments, wellness promotion, personal and home care, meal assistance, group social activities, medication and financial management, and care co-ordination previous 6 months
- $68 \%$ self-reported their health as good, very good or excellent; $70 \%$ reported being satisfied or very satisfied with their lives; $78 \%$ reported satisfaction with living environments

\section{- HEARTH (Boston, USA)}

- 136 subsidised rental units in seven different residences that offer a continuum of care provided by a multi-disciplinary team of professionals

- $95 \%$ of surveyed respondents reported a visit with primary health-care provider within

review of 97 OPEH

residents 


\begin{tabular}{|c|c|c|c|c|c|}
\hline Author (year) Title & $\begin{array}{l}\text { Publication } \\
\text { type (journal) }\end{array}$ & Country & $\begin{array}{l}\text { Study design and } \\
\text { participants }\end{array}$ & Description of shelter/housing model & Main findings \\
\hline $\begin{array}{l}\text { Lipmann (2003) Providing } \\
\text { housing and care to elderly } \\
\text { homeless men and women } \\
\text { in Australia }\end{array}$ & $\begin{array}{l}\text { Peer-reviewed } \\
\text { article } \\
\text { (Care } \\
\text { Management } \\
\text { Journals) }\end{array}$ & Australia & $\begin{array}{l}\text { Informal survey of } \\
34 \text { OPEH }\end{array}$ & $\begin{array}{l}\text { - Wintringham (Melbourne, Australia) } \\
\text { - Provides range of housing and social } \\
\text { services for up to } 600 \text { OPEH } \\
\text { Operates an aged care facility designed } \\
\text { with small cottage units with a } \\
\text { self-contained kitchen, dining room and } \\
\text { laundry, and private bedrooms and } \\
\text { ensuite bathrooms } \\
\text { - 24-hour staffing that provide } \\
\text { individualised wrap-around care to } \\
\text { match client needs }\end{array}$ & $\begin{array}{l}\text { - Many OPEH do not voluntarily engage in } \\
\text { interventions and may need additional } \\
\text { outreach and support. Critical to the success } \\
\text { of PSH is relationship-building and providing } \\
\text { a high quality of care } \\
\text { - High levels of incontinence ( } 80 \%) \text { among } \\
\text { OPEH living in shelters, dropped to } 20 \% \\
\text { once moved into Wintringham }\end{array}$ \\
\hline $\begin{array}{l}\text { Serge and Gnaedinger } \\
\text { (2003) Housing Options for } \\
\text { Elderly or Chronically III } \\
\text { Shelter Users }\end{array}$ & $\begin{array}{l}\text { Report } \\
\text { (Canada } \\
\text { Mortgage and } \\
\text { Housing } \\
\text { Corporation) }\end{array}$ & Canada & $\begin{array}{l}\text { Qualitative. } \\
\text { Case studies of } 13 \\
\text { housing models } \\
\text { and supports; } \\
\text { interviews with } 20 \\
\text { service providers }\end{array}$ & $\begin{array}{l}\text { - Five housing models for OPEH } \\
\text { (Birchmount Residence, Fairway Woods, } \\
\text { Legion Wing, Maison Claire Menard and } \\
\text { Résidence de Vieux Port) in various cities } \\
\text { in Canada have minimum age } \\
\text { requirement of } 50+ \\
\text { - The number of residents in each model } \\
\text { ranges from } 22 \text { to } 40 \\
\text { - Programmes rely on regional health } \\
\text { authorities' home support, home } \\
\text { nursing and multi-disciplinary outreach } \\
\text { services } \\
\text { - Other services include financial } \\
\text { management, supervision of } \\
\text { medications, minimum of one meal per } \\
\text { day, housekeeping and personal care } \\
\text { - Many, but not all, of the programmes } \\
\text { were developed by shelter/housing } \\
\text { providers who expanded their facilities } \\
\text { and services to respond to the } \\
\text { increasing volume and need among } \\
\text { OPEH }\end{array}$ & $\begin{array}{l}\text { - Service provider interviews revealed that } \\
\text { there are insufficient resources to meet the } \\
\text { needs of OPEH; most of the facilities } \\
\text { documented in this study have waiting lists } \\
\text { - Issues of older women experiencing } \\
\text { homelessness are relatively unknown or } \\
\text { undocumented. It is not clear whether } \\
\text { women are more easily integrated into } \\
\text { mainstream residential facilities or are } \\
\text { accommodated in the shelter/housing } \\
\text { system. No project designed specifically for } \\
\text { this population was identified } \\
\text { - Support from governments at all levels, as } \\
\text { well as inter-sectoral and inter-disciplinary } \\
\text { collaboration, appear to be keys to success } \\
\text { along with a community-development } \\
\text { approach: that is, needs are identified and } \\
\text { change is made 'from the ground up', with } \\
\text { community members and frontline providers } \\
\text { as agents of change }\end{array}$ \\
\hline & & \multicolumn{2}{|l|}{ USA } & \multicolumn{2}{|l|}{ - The HUD-VASH programme (USA-wide) } \\
\hline
\end{tabular}




\begin{tabular}{|c|c|c|c|c|c|}
\hline $\begin{array}{l}\text { Tsai et al. (2013) Life after } \\
\text { supported housing: a case } \\
\text { series of formerly } \\
\text { homeless clients in the } \\
\text { Department of Veterans } \\
\text { Affairs-Supportive Housing } \\
\text { (HUD-VASH) program } 20 \\
\text { years later }\end{array}$ & $\begin{array}{l}\text { Peer-reviewed } \\
\text { article } \\
\text { (Journal of } \\
\text { Community } \\
\text { Psychology) }\end{array}$ & & $\begin{array}{l}\text { Qualitative. } \\
\text { Semi-structured } \\
\text { interviews were } \\
\text { conducted to } \\
\text { develop three case } \\
\text { studies of veterans } \\
\text { aged } 60+\end{array}$ & $\begin{array}{l}\text { - Serves thousands of veterans annually in } \\
50 \text { states } \\
\text { - Provides Section } 8 \text { housing voucher to } \\
\text { subsidise clients' rent and case } \\
\text { management services to support } \\
\text { housing tenure }\end{array}$ & $\begin{array}{l}\text { - Illustrated the need for social and } \\
\text { community integration in supported housing } \\
\text { and the importance of case management for } \\
\text { maintaining housing }\end{array}$ \\
\hline \multicolumn{6}{|c|}{ Permanent supportive housing delivered through HF: } \\
\hline $\begin{array}{l}\text { Bamberger and Dobbins } \\
\text { (2015) A research note: } \\
\text { long-term cost } \\
\text { effectiveness of placing } \\
\text { homeless seniors in } \\
\text { permanent supportive } \\
\text { housing }\end{array}$ & $\begin{array}{l}\text { Peer-reviewed } \\
\text { article } \\
\text { (Cityscape) }\end{array}$ & USA & $\begin{array}{l}\text { Quantitative. } \\
\text { Longitudinal } \\
\text { analysis of } \\
\text { medical and } \\
\text { programme } \\
\text { records for } \\
\text { health-care costs, } \\
\text { day programme } \\
\text { usage and } \\
\text { housing outcomes } \\
\text { from } 51 \text { OPEH } \\
\text { aged } 61+\end{array}$ & $\begin{array}{l}\text { - Direct Access to Housing programme at } \\
\text { Mission Creek (San Francisco, USA) } \\
\text { - Rent fixed at US\$377/month to } \\
\text { third-party payee; tenants have all the } \\
\text { rights and responsibilities of a } \\
\text { leaseholder } \\
\text { - Eligibility requirements: monthly income } \\
\text { is more than US\$754 and currently/ } \\
\text { formerly homeless prior to being } \\
\text { institutionalised, with severe health } \\
\text { conditions but able to live } \\
\text { independently } \\
\text { - Most tenants have in-home support from } \\
\text { Mission Creek employees to assist with } \\
\text { housekeeping, food preparation, } \\
\text { activities of daily living and medication } \\
\text { schedule reminders } \\
\text { - Two case workers provide functional } \\
\text { activities, nursing services, food, } \\
\text { physical therapy, occupational therapy } \\
\text { and socialisation to qualifying tenants } \\
\text { - An Adult Day Health Center co-located } \\
\text { on-site provides services to tenants and } \\
\text { others in the community }\end{array}$ & $\begin{array}{l}\text { - } 45 \% \text { of tenants remained stably housed at } \\
7 \text {-year follow-up } \\
\text { - Death and movement to LTC were most } \\
\text { common reasons for exiting the programme. } \\
\text { Eviction accounted for } 10 \% \text { of departures } \\
\text { - Tenant health-care costs were significantly } \\
\text { lower during their } 7 \text { years in PSH compared } \\
\text { to the year prior to entry } \\
\text { - Estimated cost-savings of US\$9.2 million } \\
\text { over } 7 \text { years through prevention of } \\
\text { premature moves into LTC }\end{array}$ \\
\hline $\begin{array}{l}\text { Chung et al. (2018) } \\
\text { Housing First for older } \\
\text { homeless adults with } \\
\text { mental illness: a subgroup } \\
\text { analysis of the At Home/ }\end{array}$ & $\begin{array}{l}\text { Peer-reviewed } \\
\text { article } \\
\text { (International } \\
\text { Journal of } \\
\text { Geriatric } \\
\text { Psychiatry) }\end{array}$ & Canada & $\begin{array}{l}\text { Quantitative. } \\
\text { Randomised } \\
\text { controlled trial of } \\
1,678 \text { adults aged } \\
18-49 \text { and } 470 \\
\text { OPEH aged } 50+\end{array}$ & $\begin{array}{l}\text { - HF trial with scattered-site housing and } \\
\text { ICM or ACT in Moncton, Montreal, } \\
\text { Toronto, Vancouver and Winnipeg, } \\
\text { Canada } \\
\text { - Housing includes either ICM } \\
\text { (client-to-social worker ratio of } 20: 1 \text { ) or }\end{array}$ & $\begin{array}{l}\text { - Older adults were less likely to have mood } \\
\text { disorders with psychotic features, moderate } \\
\text { to high suicidality, or an alcohol or drug use } \\
\text { disorder, but reported more chronic health } \\
\text { conditions }\end{array}$ \\
\hline
\end{tabular}


Table 2. (Continued.)

\begin{tabular}{|c|c|c|c|c|c|}
\hline Author (year) Title & $\begin{array}{l}\text { Publication } \\
\text { type (journal) }\end{array}$ & Country & $\begin{array}{l}\text { Study design and } \\
\text { participants }\end{array}$ & Description of shelter/housing model & Main findings \\
\hline $\begin{array}{l}\text { Chez Soi randomized } \\
\text { controlled trial }\end{array}$ & & & & $\begin{array}{l}\text { ACT (team of psychiatrists, nurses, case } \\
\text { managers and peer support workers } \\
\text { with a 10:1 ratio). } \\
\text { - Subsidised housing with rent geared to } \\
\text { income (no participant paid more than } \\
30 \% \text { of their income) }\end{array}$ & $\begin{array}{l}\text { - HF significantly improved percentage of days } \\
\text { stably housed among both OPEH and } \\
\text { younger homeless adults } \\
\text { - Compared to younger adults, OPEH had } \\
\text { greater improvements in condition-specific } \\
\text { quality of life and mental health symptom } \\
\text { severity compared to treatment-as-usual } \\
\text { baseline }\end{array}$ \\
\hline $\begin{array}{l}\text { Henwood et al. (2015) } \\
\text { Aging in place within } \\
\text { permanent supportive } \\
\text { housing }\end{array}$ & $\begin{array}{l}\text { Peer-reviewed } \\
\text { article } \\
\text { (International } \\
\text { Journal of } \\
\text { Geriatric } \\
\text { Psychiatry) }\end{array}$ & USA & $\begin{array}{l}\text { Mixed methods. } \\
\text { Convergent } \\
\text { parallel design. } \\
\text { Quantitative data } \\
\text { analysis and } \\
\text { qualitative case } \\
\text { studies with } 3,990 \\
\text { adults aged } 35-49 \\
\text { and } 3,086 \text { OPEH } \\
\text { aged } 50+\end{array}$ & $\begin{array}{l}\text { - Participating PSH programmes } \\
\text { (California, USA) provided through HF in } \\
\text { a variety of settings (i.e. congregate, } \\
\text { single-site, scattered-site) } \\
\text { - Site features include home-based } \\
\text { community supports, modifications to } \\
\text { bathrooms and kitchens, and wheelchair } \\
\text { and walker accessibility }\end{array}$ & $\begin{array}{l}\text { - OPEH rehoused in PSH experienced } \\
\text { substantial declines in days spent homeless } \\
\text { and in justice system settings and increases } \\
\text { in days living independently in apartments, } \\
\text { single-room occupancies and congregate } \\
\text { settings } \\
\text { - OPEH had fewer declines in days spent } \\
\text { homeless or in justice settings compared to } \\
\text { younger adults } \\
\text { - Staff reported that OPEH have histories of } \\
\text { extended institutional care leading to } \\
\text { hopelessness, a perceived preference for } \\
\text { communal living, and requiring special } \\
\text { consideration to address complex health } \\
\text { and psycho-social needs }\end{array}$ \\
\hline \multicolumn{6}{|l|}{ Supported housing: } \\
\hline $\begin{array}{l}\text { Serge and Gnaedinger } \\
\text { (2003) Housing Options for } \\
\text { Elderly or Chronically III } \\
\text { Shelter Users }\end{array}$ & $\begin{array}{l}\text { Report } \\
\text { (Canada } \\
\text { Mortgage and } \\
\text { Housing } \\
\text { Corporation) }\end{array}$ & Canada & $\begin{array}{l}\text { Qualitative. } \\
\text { Case studies of } 13 \\
\text { housing models } \\
\text { and supports; } \\
\text { interviews with } 20 \\
\text { service providers }\end{array}$ & $\begin{array}{l}\text { - Veteran's Memorial Manor in Vancouver, } \\
\text { Canada ( } 134 \text { units), and Pioneer Inn in } \\
\text { Whitehorse, Canada ( } 18 \text { units) have } \\
\text { minimum age requirement between } \\
\text { ages } 55+\text { and } 45+ \\
\text { - Visiting service providers deliver home } \\
\text { supports, health checks and outreach } \\
\text { services } \\
\text { - Rents range from US } \$ 340 \text { to } 600 / \text { month } \\
\text { (as of } 2003 \text { ) }\end{array}$ & $\begin{array}{l}\text { - Service provider interviews suggest models } \\
\text { contribute to improved health among } \\
\text { residents and fewer hospital visits } \\
\text { - Relationship-building was identified as key } \\
\text { to successful long-term tenancies, including } \\
\text { relationship-building with the larger } \\
\text { community }\end{array}$ \\
\hline
\end{tabular}


Molinari et al. (2013)

Perceptions of

homelessness in older

homeless veterans, VA

homeless program staff

liaisons, and housing

intervention providers

\section{Peer-reviewed USA Qualitative.}

article

(Journal of

Health Care for

the Poor and

Underserved)
Interviews and

focus groups with

45 male veterans

aged $45+$ and 14

service providers
- Transitional supportive housing sites (Florida, USA) that support veterans fo up to 2 years

- Funded through the Veterans' Administration Grant Per Diem programme (USA-wide)

- Housing arrangements and eligibility requirements vary, but veterans may enter the programme from the street, shelter, unstable housing or prison
Crane and Warnes (2007)

The outcomes of rehousing older homeless people: a longitudinal study article

(Ageing \&

Society)

OP

\section{Mixed methods. \\ Longitudinal \\ interviews with 64}
- Lancefield Street Centre (London, UK) and St Anne's Community Services (Leeds and Sheffield, UK)
- Lancefield Street Centre, in operation from January 1997 to December 1998, provided two street outreach workers; an open-access, 24-hour drop-in centre; a 33-bed hostel providing temporary accommodation; access to health care and alcohol abuse programmes; and a resettlement programme
- After 24 months, 38 (59\%) remained housed. Tenancy failures were most frequent during the first 3 months and between months 16 and 18
- Tenancy failure was associated with having previously been homeless for $5+$ years or rehoused in a shared accommodation compared to independent accommodation
- Previous stable accommodation histories, regular contact with relatives or housed friends after being rehoused, engagement in activities, and regular help from housing support or care workers during the early months significantly contributed to stable rehousing after 2 years
- Of 431 clients contacted on the streets, 239 entered temporary accommodation

- Participants reported gratitude for the support provided and improved self-worth

- Peer outreach considered particularly

helpful with successful transitions

- Participants noted that it helped to have an address, a place to bathe and three meals a day; to have health-care and dental needs met; and to get help finding employment and resolving legal and financial problems

- Staff reported older veterans required more social support, had higher medical and employment needs, and were less willing to change compared to younger veterans

- Providers reported that the lack of permanent housing options, difficulty co-ordinating and publicising services, and straining to meet the diverse needs of older veterans challenged the programme 
Table 2. (Continued.)

\begin{tabular}{|c|c|c|c|c|c|}
\hline Author (year) Title & $\begin{array}{l}\text { Publication } \\
\text { type (journal) }\end{array}$ & Country & $\begin{array}{l}\text { Study design and } \\
\text { participants }\end{array}$ & Description of shelter/housing model & Main findings \\
\hline $\begin{array}{l}\text { multi-service project for } \\
\text { older homeless people }\end{array}$ & $\begin{array}{l}\text { (The } \\
\text { Gerontologist) }\end{array}$ & & $\begin{array}{l}171 \text { OPEH aged } 60 \\
+\end{array}$ & $\begin{array}{l}\text { Provided two street outreach workers; } \\
\text { an open-access, 24-hour drop-in centre; } \\
\text { a 33-bed hostel providing temporary } \\
\text { accommodation; access to health care } \\
\text { and alcohol abuse programmes; and a } \\
\text { resettlement programme }\end{array}$ & $\begin{array}{l}\text { - } 55 \text { drop-in centre users had been homeless } \\
10+\text { years and } 62 \% \text { moved into a temporary } \\
\text { accommodation } \\
\text { - Stays }>90 \text { days reduced probability of } \\
\text { returning to the streets, but those who } \\
\text { resided }<20 \text { days rarely discontinued } \\
\text { trajectories of homelessness } \\
\text { - Problematic alcohol use significantly } \\
\text { reduced the probability of a participant } \\
\text { remaining housed at the end of the study }\end{array}$ \\
\hline \multicolumn{6}{|c|}{ Shelter settings with health and social supports: } \\
\hline $\begin{array}{l}\text { Joyce and Limbos (2009) } \\
\text { Identification of cognitive } \\
\text { impairment and mental } \\
\text { illness in elderly homeless } \\
\text { men: before and after } \\
\text { access to primary health } \\
\text { care }\end{array}$ & $\begin{array}{l}\text { Peer-reviewed } \\
\text { article } \\
\text { (Canadian } \\
\text { Family } \\
\text { Physician) }\end{array}$ & Canada & $\begin{array}{l}\text { Quantitative. } \\
\text { Cross-sectional } \\
\text { review of medical } \\
\text { records }(\mathrm{N}=49 \text { ) } \\
\text { and face-to-face } \\
\text { structured } \\
\text { interview ( } \mathrm{N}=29 \text { ) } \\
\text { with OPEH aged } \\
55+\end{array}$ & $\begin{array}{l}\text { - Shelter (Toronto, Canada) } \\
\text { - Provides designated space for men aged } \\
\text { - A5+ } \\
\text { A full-time registered practical nurse and } \\
\text { a 1-day per week family physician } \\
\text { provide health-care services } \\
\text { - Clients encouraged, but not required, to } \\
\text { access services; a nurse and physician } \\
\text { provide outreach and rapport building in } \\
\text { the shelter to increase participation in } \\
\text { mental health diagnosis and treatment, } \\
\text { in order to reduce length of shelter stay } \\
\text { and support OPEH in achieving stable } \\
\text { housing } \\
\text { - Has several components in common } \\
\text { with outreach programmes that have } \\
\text { been proven to be effective, including } \\
\text { stable shelter, assistance with achieving } \\
\text { stable housing, case management, and } \\
\text { outreach by social workers, nurses and } \\
\text { shelter employees functioning together } \\
\text { to facilitate access to primary care and } \\
\text { to achieve benefits in health status }\end{array}$ & $\begin{array}{l}\text { - Thirty-six participants }(73.5 \%) \text { had previous } \\
\text { or new diagnoses (e.g. schizophrenia or } \\
\text { psychotic disorders }(\mathrm{N}=17) \text {, depression ( } \mathrm{N}= \\
11) \text {, anxiety disorders }(\mathrm{N}=3) \text {, cognitive } \\
\text { impairment }(\mathrm{N}=8) \text { and bipolar affective } \\
\text { disorder }(\mathrm{N}=1) \text { ) } \\
\text { - Following mental health assessment, } 37 \% \text { of } \\
\text { participants had mental illnesses that were } \\
\text { unrecognised or that had not been treated in } \\
\text { the past. In total, } 41 \text { participants ( } 83.7 \%) \\
\text { met the study criteria for mental illness or } \\
\text { cognitive impairment }\end{array}$ \\
\hline
\end{tabular}


O'Connell et al. (2004) Old and sleeping rough: elderly homeless persons on the streets of Boston

Journal article

(Care

Management Journals)
USA

\section{Quantitative.}

Longitudinal

analysis of

programme data

on 30 OPEH aged

60-82
- Boston Health Care for the Homeless Program (BHCHP) Street Team (Boston, USA)

- Provides acute, episodic, primary and inpatient care to homeless individuals

- Street Team (psychiatrist, internist, physician assistant, mental health clinician and two nurses) provides ICM and outreach

- BHCHP also operates a 92-bed medical respite programme (Barbara Mclnnis House)
- After 4 years, $20 \%$ of OPEH were housed in LTC; $7 \%$ in respite care; $17 \%$ in family, public, Veterans' Administration or Department of Mental Health housing; 23\% were still on the streets; $30 \%$ had passed away

- Majority of OPEH reported severe health conditions; of OPEH who passed away ( $\mathrm{N}=$ 9), seven passed away from chronic health conditions either on the street or in a LTC facility, one died from an assault and one died from being crushed by a car while sleeping rough near a construction site

- All 60 clients received mental health counselling; 92\% experienced improved Global Assessment of Functioning scores - $97 \%$ of clients were homeless upon accessing Saint Mary's; of those needing housing assistance, $95 \%$ obtained housing

- Clients reported improved confidence and coping skills: $84 \%$ reported improved coping, $78 \%$ reported more confidence, $75 \%$ reported they were less embarrassed about concerns that had brought them to Saint Mary's and $44 \%$ reported feeling more hopeful about the future

- Individuals needing personal care typically cannot be accommodated in shelters

- Support from governments at all levels, as well as inter-sectoral and inter-disciplinary collaboration, appear to be keys to success, along with a community-development approach: that is, needs are identified and change is made 'from the ground up', with community members and frontline providers as agents of change 


\begin{tabular}{|c|c|c|c|c|c|}
\hline Author (year) Title & $\begin{array}{l}\text { Publication } \\
\text { type (journal) }\end{array}$ & Country & $\begin{array}{l}\text { Study design and } \\
\text { participants }\end{array}$ & Description of shelter/housing model & Main findings \\
\hline
\end{tabular}

Case management and outreach:

Barak and Cohen (2003)

Characterizing the elderly

homeless: a 10-year study

in Israel

Peer-reviewed Israel article

(Archives of

Gerontology \&

Geriatrics)
Longitudinal

survey with 95

OPEH aged $65-88$

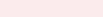

Judd et al. (2004) Housing Options and Independent

Living: Sustainable

Outcomes For Older People Who Are Homeless
Report

(Australian

Housing and

Urban

Research

Institute)
Australia Mixed methods. Literature review, survey and semi-structured interviews with 59 OPEH aged 44-89 and 55 service providers
- Municipal Health Department and mental health consultant partnership (Tel-Aviv, Israel)

- Social workers evaluate OPEH on the street and invite for further evaluation by a psychiatrist

- Eligible OPEH are assigned a case manager who allocates a housing stipend, co-ordinates funds and insurance, and can provide access to a temporary shelter while the OPEH waits for a housing subsidy or LTC placement - Provides case management as needed after rehousing

- Requires clients to participate in a support group; if they continually drop out of care while psychotic or suicidal, violently attack staff or refuse detox they are not offered services from the programme

- Assistance with Care and Housing for the Aged Program (Australia-wide)

- Federally funded programme that assists low-income, at-risk or homeless older adults through 46 agencies across the country

- Housing types include private housing, community housing, retirement communities, boarding houses and residential care facilities

- Most commonly aids with establishing and maintaining tenancy, application forms, relocation, transportation,
- $44.9 \%$ of participants reported an Axis I DSM-IV psychiatric disorder (dementia, schizophrenia, affective disorder and substance use)

- Physical comorbidity was found in $63.6 \%$ of participants

- Of participants with a mental illness, $79.5 \%$ were placed in housing (nursing home, semi-supervised housing or rented apartment) through ICM, and $94.3 \%$ remained housed after 1-year follow-up

- Some participants $(N=9)$ did not respond to rehabilitation efforts (diagnoses: $5 / 9$ paranoid schizophrenia; $3 / 9$ alcohol abuse and dependence, and 1/9 bipolar affective disorder)

- Participants reported that housing options were limited; many clients were or had previously been precariously housed

- Clients reported needing assistance establishing and maintaining housing, and positive relationships with staff were reported to be helpful

- Public and community housing were reported as preferred options, while private housing was reported as largely unsuccessful

- LTC with flexible rules was valued but in short supply, and was generally an option 

advocacy and referrals to other services

Nelson et al. (2019) The Milwaukee Continuum: older veterans and

nonveterans use Housing First to exit homelessness

\section{Peer-reviewed article \\ (Journal of \\ Humanistic}

Psychology)
USA

Qualitative.

Semi-structured interviews with 14 veterans aged 42 62 finances, housework, personal care, and
- Milwaukee Continuum of Care (Milwaukee, USA)

- Provides PSH and develops community infrastructure for veterans and non-veterans with diagnosed mental illness

- Two community-based agencies provide outreach, case management, peer support and follow-up wrap-around services disliked by clients due to cost, regulation, routine and lack of privacy

- Participants reported having weak or compromised social ties, spirituality and having fought for survival while homeless

- Participants reported that supportive care (being treated as an individual), reuniting with family and complex health-care management contributed to rehousing after 1-2 years

- The stress of transitioning to housing was reported by participants to be eased by case managers

- Participants reported that generic services may not be suitable for older women

Assistance with Care and Housing for th Aged Specialist Homelessness Services (Australia-wide)

older women's article

homelessness: service and (Australian Journal of Social Issues)

Semi-structured interviews with 14 service providers and academics

- Provides crisis accommodation, meals, emergency assistance and support with finding housing for general population older adults

- Bridges aged care and homelessness services, operating 58 centres and assisting approximately 4,000 individuals per year

- Homelessness Intervention Programme (Ontario, Canada)

- Administered through a multi-service

non-profit community agency

- Provides one senior housing outreach worker and two home support workers serving low-income homeless/at-risk seniors aged 54+ through a process that includes assessment, care planning, referral, advocacy, health care and provision of other supports

- Specialised older adult specific programm

- Specialised older adult specific programmes
and outreach into health-care settings was suggested

- Contemporary permanent housing approaches, including LTC, high-density housing, HF, shared accommodation and co-housing were suggested as potential options to meet the needs of older women with experiences of homelessness

- Clients received practical assistance with housing and financial forms $(55 \%)$ or correspondence $(38 \%)$, and almost one-quarter received assistance to obtain

entitlement benefits

and 22 service

providers.

Descriptive

statistics with 129

OPEH aged $54+$

In-depth case

- Continuity of care (care management, relationships and information) provided through the programme was highly valued

- Barriers to transitioning through the programme included limited housing options, lack of accessible community health

study and support services and limited income supports

Notes: ACT: assertive community treatment. DSM-IV: Diagnostic and Statistical Manual of Mental Disorders, 4th Edn. HF: Housing First. ICM: intensive case management. LTC: long-term care. OPEH: older people with experiences of homelessness. PSH: permanent supportive housing. UK: United Kingdom. USA: United States of America. 
reported research and programme initiatives from the United States of America (USA; $N=10)$, Canada $(\mathrm{N}=5)$, Australia $(\mathrm{N}=4)$, the United Kingdom (UK; $\mathrm{N}=2)$ and Israel $(\mathrm{N}=1)$.

\section{Data analysis}

Data charting was an iterative process whereby JH and PM independently extracted data from all 22 studies and subsequently met to compare results (Levac et al., 2010). Once data were extracted, SC reviewed the findings and participated in in-depth discussions with the other two researchers until the research team agreed on the summary of each study's findings. Through the process of reading and discussing the studies and extracted data, the research team organised findings into higher-level categories. As a result, six shelter/housing and service models were identified, reviewed and agreed upon by the research team.

\section{Findings}

The findings of this scoping review were categorised according to the provision of a physical structure and the services and supports offered to clients, resulting in: (1) long-term care (LTC), (2) permanent supportive housing (PSH), including PSH delivered through Housing First (HF), (3) supported housing, (4) transitional housing, (5) emergency shelter settings with health and social supports, and (6) case management and outreach (Table 2). Though these six categories are discussed separately to highlight their unique characteristics, there exists some overlap between them, which are noted in the sections below.

\section{(1) Long-term care (LTC)}

Research suggests that LTC designed to provide nursing care to general populations of older adults and others requiring complex care is often unprepared to manage the needs of OPEH, including alcohol use, smoking and other behaviours (Serge and Gnaedinger, 2003). Moreover, OPEH face barriers to accessing LTC as eligibility assessments are not conducted with OPEH who are staying in a shelter or on the street (Serge and Gnaedinger, 2003). In response to these challenges, the Integrated Program at Oak Bay Lodge in Victoria, Canada (which was discontinued in 2002) designated three beds in a 282-bed LTC facility for older adults with difficulties with substance use, including some who were cyclically homeless (Serge and Gnaedinger, 2003). Clients of the Integrated Program had access to all supports available in the LTC facility, including 24-hour nursing and three meals a day, and were supported by a designated outreach worker (Serge and Gnaedinger, 2003). Outcomes of the effectiveness of this model are unknown.

In a similar model in Melbourne, Australia, Wintringham, Wicking Project I and II provides long-term residential care for OPEH with dementia resulting from alcohol-related acquired brain injury in a four-bedroom community home (in Wicking I) and a 60-bed residential care facility with individual bedrooms and common area (in Wicking II). These programmes provide intensive, individualised recreational support and specialised case management and recreational 
support (Rota-Bartelink, 2016). When compared to control OPEH clients, Wicking Project clients were less expensive. Moreover, Wicking I and II helped participants reduce the frequency and impact of challenging behaviours, improved health and wellbeing, and decreased levels of hospitalisation and crisis and criminal justice service use (Rota-Bartelink, 2016).

\section{(2) Permanent supportive housing (PSH)}

PSH models provide affordable housing and supportive services for people experiencing chronic homelessness in either scattered or single-site settings (Brown et al., 2013b; Henwood et al., 2015). Services range widely, but include social supports (e.g. case management, meals, home-making services) and/or medical supports (e.g. nursing, psychiatric treatment, substance use counselling) (Brown et al., 2013b; Bamberger and Dobbins, 2015).

Operating in Boston, MA, HEARTH (formerly the Committee to End Elder Homelessness) provides outreach services and subsidised PSH rental units for $\mathrm{OPEH}$ in seven different residences that offer a continuum of care provided by a multidisciplinary team of professionals (e.g. social workers, care aides) and 24-hour staffing to support complex physical and mental health challenges (Gibeau, 2001; Gonyea and Bachman, 2009; Brown et al., 2013b). Fairway Woods in Victoria, Canada offers PSH with a variety of common spaces that promote social interaction and communitybuilding for OPEH, as well as meals and 24-hour medical and social support (Gnaedinger, 2007). Operating under a harm reduction approach (Pauly et al., 2011), Wintringham in Melbourne, Australia delivers a variety of medical, housing and outreach services for over $600 \mathrm{OPEH}$, including a PSH programme that provides small home-like cottages with a self-contained kitchen, dining room, laundry and private bedrooms that are staffed 24 hours (Lipmann, 2003). Similarly, the Résidence $d u$ Vieux Port in Montréal, Canada provides PSH for OPEH with mental health and/or alcohol use conditions and permits on-site alcohol use (Serge and Gnaedinger, 2003). Finally, while all PSH programmes provide subsidised housing, the US Housing and Urban Development-Veterans Affairs Supportive Housing (HUD-VASH) programme, which provides PSH through wrap-around case management services to veterans experiencing homelessness, is the only identified PSH model that uses a housing voucher (i.e. a government subsidy paid directly to the landlord) as a method of subsidising rent (Tsai et al., 2013).

The existing research indicates that placement in PSH contributes to improved relationships, health, wellbeing, stability, connection to health-care providers, and feelings of satisfaction and security among OPEH (Gnaedinger, 2007; Gonyea and Bachman, 2009). Furthermore, research suggests that PSH is an appropriate setting for OPEH who may be too young or not a good 'fit' in aged care facilities, but whose needs are too complex for shelter accommodation (Serge and Gnaedinger, 2003). While transitions into PSH can be stressful for some OPEH, the research suggests that individualised, person-centred outreach and case management improves healthy behaviours and facilitates reconnections with family, which contribute to reduced stress, recovery and perceptions of stable rehousing (Nelson et al., 2019). Moreover, ongoing case management and support with substance use and mental health challenges are important to OPEH's stability in PSH 
(Tsai et al., 2013), and caring and helpful service providers contribute to OPEH's positive perceptions of PSH (Gibeau, 2001). In North America, one sub-category of PSH has been implemented successfully through HF programmes.

\section{(2a) PSH delivered through HF}

As a sub-category, some PSH models are delivered using a HF philosophy. HF takes a person-centred, rights-based approach to rehousing to provide direct access to housing for people experiencing homelessness living with mental illness, without prerequisites that OPEH are sober or participate in treatment (Bamberger and Dobbins, 2015; Henwood et al., 2015; Chung et al., 2018). Furthermore, HF clients are supported through either intensive case management (ICM: weekly meetings with a case manager to develop and implement an individualised care plan) or assertive community treatment (24-hour access to a care team of medical providers, case managers and peer support workers who collaboratively address client concerns and implement individualised care plans) (Chung et al., 2018).

Mission Creek Apartments in San Francisco, CA have no prerequisites for sobriety and is co-located with an adult day centre that offers functional activities, nursing services and opportunities for socialisation to tenants and community members (Bamberger and Dobbins, 2015). Research suggests that PSH HF strategies increase the number of days OPEH are stably housed, while reducing mental health symptom severity (Chung et al., 2018). Henwood et al. (2015) found that after engagement with PSH HF services, OPEH experienced a substantial decline in days spent homeless or in justice settings and an increase in days spent living independently in an apartment. Furthermore, PSH HF models have been found to contribute to longer tenancy outside a skilled nursing facility (Bamberger and Dobbins, 2015).

\section{(3) Supported housing}

While similar to PSH in that it offers residents permanent housing, supported housing deviates from PSH in that services and supports are not integrated with the housing, but are offered separately. Two models of supported housing identified (Veteran's Memorial Manor in Vancouver, Canada has 134 units; and Pioneer Inn in Whitehorse, Canada has 18 units) have minimum age requirements between 55+ and 45+ years old, respectively, and bring service providers on-site to deliver home support, nursing, health checks and multi-disciplinary outreach services (Serge and Gnaedinger, 2003). These services support residents' daily activities and research suggests that supported housing contributes to improved health among residents, fewer hospital visits and reduced health-care costs (Serge and Gnaedinger, 2003). In addition, relationship-building has been identified as key to successful long-term tenancies, including integration into the larger community (Serge and Gnaedinger, 2003).

\section{(4) Transitional housing}

Transitional housing provides time-limited move-in and rental assistance and/or physical accommodation to individuals with the aim of providing quick access to housing, as well as support stabilising, so individuals can move into permanent housing (Gaetz, 2014). The US Veterans' Administration Grant Per Diem programme 
offers funding for up to two years of community-based transitional housing and case management to veterans living on the street, in shelters, unstable housing or prison (Molinari et al., 2013). In operation from 1997 to 1998, the Lancefield Street Centre in London, UK provided services to $\mathrm{OPEH}$ to enable progression from street living to resettlement in long-term accommodation, including two street outreach workers, a 24-hour drop-in centre, a 33-bed hostel providing temporary accommodation, access to health-care and alcohol-use programmes, and a resettlement programme (Warnes and Crane, 2000; Crane and Warnes, 2007).

Research suggests that having a stable address, access to meals and bathing facilities, assistance with financial, legal and employment issues, and co-ordinated health and dental care support the self-worth and achievement of permanent housing goals for OPEH (Molinari et al., 2013). In addition, longer stays in transitional housing have been found to reduce OPEH's chances of returning to the streets (Warnes and Crane, 2000). Having had a previously stable accommodation history, engagement in activities, regular contact with relatives and regular assistance from housing support or care workers during the early months of being in transitional housing have been associated with housing stability (Crane and Warnes, 2007).

\section{(5) Emergency shelter settings with health and social supports}

Though some research suggests that homeless shelters can be unsupportive environments for OPEH with complex health conditions (Serge and Gnaedinger, 2003; Burns, 2016; Canham et al., 2020), accessible shelter settings with appropriate health and social services have been found to support OPEH during housing crises (McLeod and Walsh, 2014). In Toronto, Canada one shelter offers health-care services to OPEH delivered by a full-time registered practical nurse and a drop-in family physician, including screening for mental health and cognitive impairment (Joyce and Limbos, 2009). Also in Toronto, the Rotary Transition Centre provides shelter where homeless persons accessing acute care can shower, eat and wash clothes while psychiatrists, students and residents serve clients through the Psychiatry Shelter Outreach Program (Serge and Gnaedinger, 2003). Another model, the Boston Healthcare for the Homeless Program (BHCHP), employs a 'street team' (i.e. a psychiatrist, internist, physician assistant, mental health clinician and two nurses) which connects with and provides health-care outreach to OPEH living on the streets and in shelters, the majority of whom report severe health conditions (O'Connell et al., 2004). BHCHP also operates the Barbara McInnis House, a 92-bed medical respite programme for OPEH (O'Connell et al., 2004). Saint Mary's Center in California provides OPEH-directed services, including outreach, housing system navigation, medical care, mental health services, financial management, substance use counselling, support groups and a winter shelter (Proehl, 2007).

Research suggests that bringing medical resources into shelters can help rehouse OPEH in supportive settings that meet their needs, including LTC, respite care and public housing (O'Connell et al., 2004). Furthermore, having health-care services integrated into shelter settings has been found to help identify and treat previously undiagnosed cognitive impairment and mental illness, resulting in positive health, wellbeing and tenancy outcomes (Crane and Warnes, 2007; Joyce and Limbos, 
2009). For example, among OPEH who received mental health counselling in Saint Mary's Center, the majority reported improved confidence and coping skills (Proehl, 2007). Moreover, continued engagement with health and social services has been found to improve the likelihood of OPEH securing and maintaining permanent accommodation (Proehl, 2007).

\section{(6) Case management and outreach}

Finally, while not providing a physical structure, case management and outreach was identified as a model to support OPEH. In particular, a flexible and respectful approach to care, building trust and personal relationships, caring attitudes and helpfulness from staff, provision of supportive services and advocacy, and access to a broad range of available, affordable housing options have been reported as essential components of programming for OPEH (Gibeau, 2001; Lipmann, 2003; Judd et al., 2004; Petersen, 2015). Noted previously, HEARTH (Boston) employs a team of case managers who provide outreach to OPEH living in shelters and precarious housing to assist with housing navigation, health-care co-ordination, financial issues, substance use treatment and securing benefits (Gibeau, 2001; Brown et al., 2013b). In Milwaukee, WI, the Milwaukee Continuum of Care connects older veterans and non-veterans experiencing homelessness to HF programmes using peer support outreach specialists, who build trusting relationships with clients and provide linkages to case managers who design personalised care plans with clients and co-ordinate wrap-around support through the rehousing process (Nelson et al., 2019). Similarly, a homelessness intervention programme in Toronto, Canada employs an outreach worker who provides assessment, care planning, practical assistance, referrals, advocacy and follow-up to assist in the placement and maintenance of permanent housing for OPEH (Ploeg et al., 2008). An outreach programme in Tel Aviv, Israel utilises an ICM team of case managers, criminologists and a psychiatrist to identify OPEH in the community, evaluate their mental health and assist with placement in appropriate supported or independent housing (Barak and Cohen, 2003). Finally, in Australia, the federally funded Assistance with Care and Housing for the Aged Program assists OPEH to establish and maintain housing tenancy, complete application forms, transportation, personal care, meals, housework, financial assistance, advocacy, crisis accommodation and referral to other services (Judd et al., 2004; Petersen, 2015).

The available research amongst OPEH who may experience barriers or challenges to accessing support suggests that case management (including ICM) and outreach yields positive health and housing outcomes (Barak and Cohen, 2003; O'Connell et al., 2004; Nelson et al., 2019). For OPEH, including those living with mental and physical illness, case management and outreach have been found to contribute to getting placed in housing and maintaining long-term housing (Barak and Cohen, 2003; O'Connell et al., 2004). For OPEH, there are a range of housing types that meet different levels of health and social need, and navigating wait times and the stress of transitioning into housing was reportedly eased when assisted by case managers (Petersen, 2015; Nelson et al., 2019). Moreover, continuity of care and practical assistance in completing housing and financial forms has been reported as highly valued by OPEH receiving outreach services (Ploeg et al., 2008). 


\section{Discussion}

This review identified six shelter/housing options, supports and interventions for $\mathrm{OPEH}$ and, where possible, the impact of these models on health and housing outcomes for OPEH. Models were categorised according to the provision of a physical structure and the formal services and supports offered. This categorisation aligns with research that suggests that OPEH have a broad range of needs, which require diverse options, supports and interventions (Serge and Gnaedinger, 2003; Burns and Sussman, 2019; Canham et al., 2020) and builds upon the categorisation by Humphries and Canham (2019) (HF, PSH and multi-service interventions) and McGhie et al. (2013) (affordable housing, supported and supportive housing, emergency housing/shelter, and LTC).

Providing the highest level of support, LTC and PSH models provide permanent housing with on-site health and social supports. Both LTC models identified in this review support OPEH with drug- and alcohol-related challenges, including acquired brain injury. Prior research has identified OPEH who are chronic alcohol users as having few or no supports available because options for OPEH are too expensive, do not permit the use of alcohol and do not support individuals who experience alcohol-related behavioural issues (Canham et al., 2020). However, the Wicking Projects and the Integrated Program reported on the value - to both individual outcomes and health-care cost savings - of providing 24-hour individualised support to sub-populations of OPEH who chronically use alcohol.

PSH models were the most commonly identified shelter/housing option for $\mathrm{OPEH}$, serving a diverse range of individuals in the USA, UK and Australia in a range of housing typologies (e.g. scatter site, congregate). While a few models identified specific target populations of OPEH, including veterans (Tsai et al., 2013) and those living with mental health disorders (Chung et al., 2018), most research did not describe population-specific programme development or outcomes for any subgroups of OPEH. Instead, studies focused on the similarities across models centred on the integration of housing and services, and the benefits of PSH for housing, health and social outcomes for OPEH. Supported housing models, of which only two were identified (Serge and Gnaedinger, 2003), were also found to result in positive outcomes for OPEH, though these models require services to be brought on-site by health and social support agencies.

Two transitional housing models for OPEH were identified, including one that provides transitional supportive housing to older veterans for up to two years (Molinari et al., 2013), and a second (Lancefield Street Centre) that supports rehousing single older adults in the UK from homeless hostels into permanent housing (Warnes and Crane, 2000; Crane and Warnes, 2007). Both models supported single, unattached OPEH, but varied in how OPEH were supported to move from the street, shelter, unstable housing or prison into permanent housing. Similar to findings from other models identified in this review, OPEH clients in transitional programmes were more successful in rehousing when they were able to maintain connection to positive peer support and formal social support, and less successful if clients had long histories of homelessness or problematic alcohol use.

Several shelters that provide health and social supports to OPEH were identified in both the USA and Canada; similar to transitional models, shelters provide 
accommodation and services, but only temporarily. Regardless of country or shelter site, key features that were found to support OPEH include inter-professional health and social care teams that collaborate to serve clients on the street or in the shelter. In addition, the identification of previously undiagnosed cognitive and mental health conditions was a reported benefit (Joyce and Limbos, 2009). Research on the identified shelter models did not distinguish between client outcomes based on gender or race/ethnicity. Instead, the primary focus of programme delivery and similarity among OPEH clients across all sites and studies was the need for complex and integrated care co-ordination, whether it be for detox, rehabilitation or medical respite (O'Connell et al., 2004; Proehl, 2007).

Finally, while case management and outreach do not provide a physical structure where OPEH can sleep, research from the USA, UK, Australia and Israel suggested the importance of this model for offering OPEH with the services and supports needed to establish and maintain housing, access practical and financial assistance, and have continuity in their physical and mental health care. Of the five models identified in this category, several (Barak and Cohen, 2003; Nelson et al., 2019) emphasised the value of case management in serving OPEH clients who have mental health disorders. Only one (Petersen, 2015) described the need for genderspecific considerations, suggesting that generic services may not be suitable. Taken together, there was a notable gap in the literature on which sub-populations of OPEH are best served by the different categories of shelter/housing support.

\section{Alignment with conceptualisations of ageing in the right place}

Research on ageing in the right place recognises that where older persons live impacts their ability to age optimally and must match their unique lifestyles and vulnerabilities - in other words, the 'right' set of housing, health and social supports can enable diverse groups of older adults (including older adults with limited income and/or chronic complex health conditions) to age in a positive way (Golant, 2015). While ageing in place for general populations of housed older adults is supported through physical, psychological, social and functional aspects of the home and community environment (Greenfield, 2012; Sixsmith et al., 2017), our findings demonstrate that, due to the unique needs of OPEH, additional support is needed in order to promote ageing in 'the right' place (Woolrych et al., 2015; Canham et al., 2018). Prior research has indicated that ageing in the right place for OPEH requires shelter/housing models to include health and social supports that contribute to positive outcomes, a sense of belonging and community reintegration (Waldbrook, 2015; Grenier et al., 2016a). Building upon this, our review suggests additional considerations for promoting ageing in the right place for diverse OPEH, including (a) social connection and trusting relationships, including from peer supports; (b) individualised services and supports, including 24-hour on-site physical and mental health care; and (c) permanent supportive housing options that are co-located with opportunities for socialisation and transportation to off-site services. These considerations are suggestive of not merely the individual-level aspects of how to support OPEH to age in the right place but attend to the mezzo- and macro-level systems and policies (Bronfenbrenner and Morris, 2006) that enable or challenge ageing in the right place. For instance, in 
regions where there is limited affordable housing, the ability for OPEH to remain in their homes or communities of choice becomes less feasible (Canham et al., 2018).

Aligned with previous literature (Burns, 2016; Walsh et al., 2016; Bazari et al., 2018; Finlay et al., 2020), findings from this review suggest that social connection and relationship-building among OPEH, service providers and the surrounding community is highly valued by both OPEH and staff, and is associated with successfully establishing and maintaining housing (Gibeau, 2001; Lipmann, 2003; Judd et al., 2004; Tsai et al., 2013). Indeed, restoring social connections promotes feelings of value and self-worth among OPEH (Gonyea and Melekis, 2017). Moreover, continuity of care during the rehousing process has been found to rebuild a sense of trust and promote a sense of social connection that buffers against future homelessness (Crane and Warnes, 2007; Ploeg et al., 2008). Beyond formal relationships with staff, connection with peers who have successfully navigated rehousing has been suggested as an avenue to combat the shame, anxiety and stigma experienced by OPEH (Grenier et al., 2016b). The value of social connection and trusting relationships cannot be overstated, as strong social networks are integral to supporting OPEH who are at risk of isolation and prolonged homelessness (Kimbler et al., 2017).

In light of findings that housing and supports contribute to decreased homelessness and days involved in justice settings among OPEH (Henwood et al., 2015), while increasing health and quality-of-life outcomes (Chung et al., 2018) and cost savings on health-care expenditures (Bamberger and Dobbins, 2015), models that want to promote ageing in the right place for OPEH should offer individualised services and supports. Highlighted in this review, the individualised service needs of diverse OPEH may require co-ordinated health care or 24-hour on-site physical and mental health care, substance use counselling, housing navigation assistance (i.e. finding and maintaining permanent accommodation) and financial support. Such individualised support should integrate culturally sensitive (Chau et al., 2011) and trauma-informed approaches by focusing on individual strengths, safety and personal development (McDonald et al., 2007; Hopper et al., 2010; Gaetz et al., 2013). Coupling culturally sensitive, trauma-informed practice with flexible and individualised (i.e. person-centred) health supports (Henwood et al., 2013) and adequate resources (Canham et al., 2019) within shelter/housing can promote ageing in the right place for OPEH (Humphries and Canham, 2019).

Finally, despite limited availability, there is some indication that models that co-locate permanent supportive housing with opportunities for socialisation and transportation to off-site services are well-suited to meet the diverse physical, mental and social needs of OPEH (Bamberger and Dobbins, 2015). Such models have the opportunity to support nutrition, social connection, physical and mental health therapy, and more in a central location. Co-located, community-based models that recognise and support OPEH-specific needs and activities have significant potential to promote ageing in the right place for this population. In addition, models that prevent eviction are needed (Crane et al., 2005; Walsh et al., 2015), including utility subsidies, which reduce financial strain for low-income older adults (Bottomley, 2001).

Several limitations to this scoping review require noting. We limited our search to peer-reviewed and grey literature in which empirical data were reported. This 
may have excluded reports that describe shelter/housing models that support various sub-groups of $\mathrm{OPEH}$, including Indigenous elders, lesbian, gay, bisexual, transgender, queer or questioning, and two-spirit (LGB+) seniors, older veterans or older women fleeing violence. Moreover, as a result of publication bias, nonsignificant findings are rarely published and, therefore, not captured in this review. Additional efforts are needed to identify the distinct needs of sub-groups of OPEH and to develop models to support their capacity to age in the right place. In addition, future research is needed to evaluate the effectiveness of different models that have not been subject to rigorous evaluation in order to determine what 'works and for whom' (Canadian Homelessness Research Network, 2013). As OPEH are a heterogeneous population, the models that best support different sub-groups of OPEH remain to be determined.

While we examined literature from 1999 to 2019,13 of the 22 sources were published between 1999 and 2009, which may impact their relevance to the experiences of OPEH today. We were also limited to reviewing literature available in English. In addition, our identification of models embedded within different housing and health-care delivery and policy systems does not enable us to achieve consensus about best practices. Nevertheless, we were able to identify a broad range of models. Finally, our review may be limited in that we did not assess the quality of evidence reported in the research reviewed, as this is not the goal of a scoping review. Instead, our goal was to determine the extent, range and nature of existing literature on shelter/housing options, supports and interventions for OPEH, which we achieved.

Findings from this review have enabled us to categorise and describe shelter/ housing options, supports and interventions for OPEH. This categorisation can be used as a template for designing and implementing future solutions, while serving as a foundation for research evaluating efficacy and fit of different models that serve as best practices for specific sub-groups of OPEH to age in the right place. Building such an evidence base has significant potential to advance policy, practice and design to better meet the unique needs of diverse OPEH.

Financial support. This research, 'Aging in the Right Place: Building Capacity to Improve Supportive Housing for Older People Experiencing Homelessness in Montréal, Calgary, and Vancouver', was supported by a Partnership Development Grant funded by the Canadian Mortgage Housing Corporation (CMHC); and the Social Sciences and Humanities Research Council (SSHRC). The opinions and interpretations in this publication are those of the authors and do not necessarily reflect those of CMHC or SSHRC.

Conflict of interest. The authors declare no conflicts of interest.

\section{References}

Arksey H and O'Malley L (2005) Scoping studies: towards a methodological framework. International Journal of Social Research Methodology 8, 19-32.

Bamberger JD and Dobbins SK (2015) A research note: long-term cost effectiveness of placing homeless seniors in permanent supportive housing. Cityscape 17, 269-277.

Barak Y and Cohen A (2003) Characterizing the elderly homeless: a 10-year study in Israel. Archives of Gerontology \& Geriatrics 37, 147-155.

Bazari A, Patanwala M, Kaplan LM, Auerswald CL and Kushel MB (2018) 'The thing that really gets me is the future': symptomatology in older homeless adults in the HOPE HOME study. Journal of Pain and Symptom Management 56, 195-204. 
Bigonnesse C and Chaudhury H (2020) The landscape of aging in place in gerontology literature: emergence theoretical perspectives and influencing factors. Journal of Aging and Environment 34, 233-251.

Bottomley JM (2001) Energy assistance programs: keeping older adults housed and warm. Topics in Geriatric Rehabilitation 17, 71-81.

Bronfenbrenner U and Morris PA (2006) The bioecological model of human development. In Damon W and Lerner RM (eds), Handbook of Child Psychology: Theoretical Models of Human Development. New York, NY: Wiley, pp. 793-828.

Brown RT, Kiely DK, Bharel M and Mitchell SL (2013a) Factors associated with geriatric syndromes in older homeless adults. Journal of Health Care for the Poor and Underserved 24, 1-14.

Brown RT, Thomas LM, Cutler DF and Hinderlie M (2013b) Meeting the housing and care needs of older homeless adults: a permanent supportive housing program targeting homeless elders. Seniors Housing \& Care Journal 21, 126-135.

Brown RT, Hemati K, Riley ED, Lee CT, Ponath C, Tieu L, Guzman D and Kushel MB (2017) Geriatric conditions in a population-based sample of older homeless adults. The Gerontologist 57, 757-766.

Burns VF (2016) Oscillating in and out of place: experiences of older adults residing in homeless shelters in Montreal, Quebec. Journal of Aging Studies 39, 11-20.

Burns VF and Sussman T (2019) Homeless for the first time in later life: uncovering more than one pathway. The Gerontologist 59, 251-259.

Canadian Homelessness Research Network (2013) What Works and for Whom? A Framework for Designing and Implementing Promising Practices Research. Toronto: Canadian Homelessness Research Network Press.

Canham SL, Battersby L, Fang ML, Wada M, Barnes R and Sixsmith A (2018) Senior services that support Housing First in Metro Vancouver. Journal of Gerontological Social Work 61, 104-125.

Canham SL, Davidson S, Custodio K, Mauboules C, Good C, Wister AV and Bosma H (2019) Health supports needed for homeless persons transitioning from hospitals. Health and Social Care in the Community 27, 531-545.

Canham SL, Custodio K, Mauboules C, Good C and Bosma H (2020) Health and psychosocial needs of older adults who are experiencing homelessness following hospital discharge. The Gerontologist 60, 715-724.

Chau RCM, Yu SWK and Tran CTL (2011) The diversity based approach to culturally sensitive practices. International Social Work 54, 21-33.

Chung TE, Gozdzik A, Palma Lazgare LI, To MJ, Aubry T, Frankish J, Hwang SW and Stergiopoulos V (2018) Housing First for older homeless adults with mental illness: a subgroup analysis of the At Home/ Chez Soi randomized controlled trial. International Journal of Geriatric Psychiatry 33, 85-95.

Crane M and Warnes AM (2007) The outcomes of rehousing older homeless people: a longitudinal study. Ageing \& Society 27, 891-918.

Crane M and Warnes AM (2010) Homelessness among older people and service responses. Reviews in Clinical Gerontology 20, 354-363.

Crane M, Byrne K, Fu R, Lipmann B, Mirabelli F, Rota-Bartelink A, Ryan M, Shea R, Watt R and Warnes AM (2005) The causes of homelessness in later life: findings from a 3-nation study. Journals of Gerontology: Psychological Sciences and Social Sciences 60B, S152-S159.

Culhane D, Treglia D, Byrne T, Metraux S, Kuhn R and Doran K (2019) The Emerging Crisis of Aged Homelessness: Could Housing Solutions Be Funded from Avoidance of Excess Shelter, Hospital, and Nursing Home Costs? Philadelphia, PA.

Finlay JM, Gaugler JE and Kane RL (2020) Ageing in the margins: expectations of and struggles for 'a good place to grow old' among low-income older Minnesotans. Ageing \& Society 40, 759-783.

Furlotte C, Schwartz K, Koornstra JJ and Naster R (2012) 'Got a room for me?' Housing experiences of older adults living with HIV/AIDS in Ottawa. Canadian Journal on Aging 31, 37-48.

Gaetz S (2014) Coming of Age: Reimagining the Response to Youth Homelessness in Canada. Toronto: The Canadian Onservatory on Homelessness Press.

Gaetz S, Scott F and Gulliver T (2013) Housing First in Canada: Supporting Communities to End Homelessness. Toronto: Canadian Homelessness Research Network Press.

Gaetz S, Dej E, Richter T and Redman M (2016) The State of Homelessness in Canada 2016: A Canadian Observatory on Homelessness Research Paper. Toronto: Canadian Observatory on Homelessness Press. 
Garibaldi B, Conde-Martel A and O'Toole TP (2005) Self-reported comorbidities, perceived needs, and sources for usual care for older and younger homeless adults. Journal of General Internal Medicine 20, 726-730.

Gibeau JL (2001) Home free: an evolving journey in eradicating elder homelessness. Topics in Geriatric Rehabilitation 17, 22-52.

Gnaedinger N (2007) Supportive Housing for Homeless and Hard-to-house Seniors: An In-depth Study of Fairway Woods, Final Report. Ottawa, ON: Canada Mortgage and Housing Corporation.

Golant S (2015) Aging in the Right Place. Baltimore, MD: Health Professions Press.

Gonyea JG and Bachman SS (2009) Ending Elder Homelessness: The Importance of Service-enriched Housing. Boston, MA: HEARTH.

Gonyea JG and Melekis K (2017) Older homeless women's identity negotiation: agency, resistance, and the construction of a valued self. The Sociological Review 65, 67-82.

Gonyea JG, Mills-Dick K and Bachman SS (2010) The complexities of elder homelessness, a shifting political landscape and emerging community responses. Journal of Gerontological Social Work 53, 575-590.

Greenfield EA (2012) Using ecological frameworks to advance a field of research, practice, and policy on aging-in-place initiatives. The Gerontologist 52, 1-12.

Grenier A, Barken R and McGrath C (2016a) Homelessness and aging: the contradictory ordering of 'house' and 'home'. Journal of Aging Studies 39, 73-80.

Grenier A, Sussman T, Barken R, Bourgeois-Guérin V and Rothwell D (2016b) 'Growing old' in shelters and 'on the street': experiences of older homeless people. Journal of Gerontological Social Work 59, 458-477.

Henwood BF, Shinn M, Tsemberis S and Padgett DK (2013) Examining provider perspectives within Housing First and traditional programs. American Journal of Psychiatric Rehabilitation 16, 262-274.

Henwood BF, Katz ML and Gilmer TP (2015) Aging in place within permanent supportive housing. International Journal of Geriatric Psychiatry 30, 80-87.

Homeless Link (2014) The Unhealthy State of Homelessness: Health Audit Results. London, UK: Homeless Link.

Hopper EK, Bassuk EL and Olivet J (2010) Shelter from the storm: trauma-informed care in homelessness services settings. Open Health Services and Policy Journal 3, 80-100.

Humphries J and Canham SL (2019) Conceptualizing the shelter and housing needs and solutions of homeless older adults. Housing Studies. Available online doi: 10.1080/02673037.2019.1687854.

Joyce DP and Limbos M (2009) Identification of cognitive impairment and mental illness in elderly homeless men: before and after access to primary health care. Canadian Family Physician 55, 1110-1111.e6.

Judd B, Kavanagh K, Morris A and Naidoo Y (2004) Housing Options and Independent Living: Sustainable Outcomes for Older People Who Are Homeless. Melbourne: Australian Housing and Urban Research Institute.

Khandor E and Mason K (2007) The Street Health Report 2007: The Health of Toronto's Homeless Population. Toronto: Street Health.

Kimbler KJ, DeWees MA and Harris AN (2017) Characteristics of the old and homeless: identifying distinct service needs. Aging \& Mental Health 21, 190-198.

Levac D, Colquhoun H and O'Brien KK (2010) Scoping studies: advancing the methodology. Implementation Science 5, 69.

Lipmann B (2003) Providing housing and care to elderly homeless men and women in Australia. Care Management Journals 4, 23-30.

McDonald L, Dergal J and Cleghorn L (2007) Living on the margins: older homeless adults in Toronto. Journal of Gerontological Social Work 49, 19-46.

McDonald L, Donahue P, Janes J and Cleghorn L (2009) Understanding the health, housing, and social inclusion of formerly homeless older adults. In David Hulchanski J, Campsie P, Chau S, Hwang S and Paradis E (eds). Finding Home: Policy Options for Addressing Homelessness in Canada (e-book), Chapter 2.5. Toronto, Cities Centre, University of Toronto.

McGhie L, Barken R and Grenier A (2013) Literature Review: Housing Options for Older Homeless People. Hamilton, Canada: Gilbrea Centre for Studies in Aging, McMaster University.

McLeod H and Walsh CA (2014) Shelter design and service delivery for women who become homeless after age 50. Canadian Journal of Urban Research 23, 23-38. 
Means R (2007) Safe as houses? Ageing in place and vulnerable older people in the UK. Social Policy \& Administration 41, 65-85.

Molinari VA, Brown LM, Frahm KA, Schinka JA and Casey R (2013) Perceptions of homelessness in older homeless veterans, VA homeless program staff liaisons, and housing intervention providers. Journal of Health Care for the Poor and Underserved 24, 487-498.

Nelson DA, Morzinski J and Flower M (2019) The Milwaukee Continuum: older veterans and nonveterans use Housing First to exit homelessness. Journal of Humanistic Psychology. Available online doi: $10.1177 / 0022167819866523$.

O'Connell JJ, Roncarati JS, Reilly EC, Kane CA, Morrison SK, Swain SE, Allen JS and Jones K (2004) Old and sleeping rough: elderly homeless persons on the streets of Boston. Care Management Journals 5, 101-106.

Pani-Harreman KE, Bours GJJW, Zander I, Kempen GIJM and van Duren JMA (2021) Definitions, key themes and aspects of 'ageing in place': a scoping review. Ageing \& Society 41, 2026-2059.

Pauly B, Reist D, Schactman C and Belle-Isle L (2011) Housing and Harm Reduction: A Policy Framework for Greater Victoria. Centre for Addictions Research of BC. Available at https://www.uvic.ca/research/ centres/carbc/assets/docs/report-housing-and-harm-reduction.pdf.

Petersen M (2015) Addressing older women's homelessness: service and housing models. Australian Journal of Social Issues 50, 419-438.

Ploeg J, Hayward L, Woodward C and Johnston R (2008) A case study of a Canadian homelessness intervention programme for elderly people. Health and Social Care in the Community 16, 593-605.

Proehl RA (2007) Social justice, respect, and meaning-making: keys to working with the homeless elderly population. Health \& Social Work 32, 301-307.

Rota-Bartelink A (2016) Wicking Project II: The Provision of Skilled Specialist Consultancy Services to People Living with Highly Complex Needs and Their Caregivers. Melbourne: Wintringham.

Serge L and Gnaedinger N (2003) Housing Options for Elderly or Chronically Ill Shelter Users. Ottawa: Canada Mortgage and Housing Corporation.

Sixsmith J, Fang ML, Woolrych R, Canham SL, Battersby L and Sixsmith A (2017) Ageing well in the right place: partnership working with older people. Working with Older People 21, 40-48.

Stergiopoulos V and Herrmann N (2003) Old and homeless: a review and survey of older adults who use shelters in an urban setting. Canadian Journal of Psychiatry 48, 374-380.

Sudore RL, Cuervo IA, Tieu L, Guzman D, Kaplan LM and Kushel M (2018) Advance care planning for older homeless-experienced adults: results from the health outcomes of people experiencing homelessness in older middle age study. Journal of the American Geriatrics Society 66, 1068-1074.

Torres-Gil F and Hofland B (2012) Vulnerable populations. In Cisneros H, Dyer-Chamberlain M and Hickie J (eds), Independent for Life: Homes and Neighborhoods for an Aging America. Austin, TX: University of Texas Press, pp. 221-232.

Tsai J, Klee A, Remmele J and Harkness L (2013) Life after supported housing: a case series of formerly homeless clients in the Department of Veterans Affairs-Supportive Housing (HUD-VASH) program 20 years later. Journal of Community Psychology 41, 1039-1046.

Waldbrook N (2015) Exploring opportunities for healthy aging among older persons with a history of homelessness in Toronto, Canada. Social Science and Medicine 128, 126-133.

Walsh CA, Hewson J, Paul K, Gulbrandsen C and Dooley D (2015) Falling through the cracks: exploring the subsidized housing needs of low-income preseniors from the perspectives of housing providers. SAGE Open 5, 3.

Walsh CA, Lorenzetti L, St-Denis N, Murwisi P and Lewis TR (2016) Community voices: insights on social and human services from people with lived experiences of homelessness. Review of Social Sciences 1, 27-41.

Warnes AM and Crane MA (2000) The achievements of a multiservice project for older homeless people. The Gerontologist 40, 618-626.

Woolrych R, Gibson N, Sixsmith J and Sixsmith A (2015) 'No home, no place': addressing the complexity of homelessness in old age through community dialogue. Journal of Housing for the Elderly 29, 233-258.

Cite this article: Canham SL, Humphries J, Moore P, Burns V, Mahmood A (2022). Shelter/housing options, supports and interventions for older people experiencing homelessness. Ageing \& Society 42, 2615-2641. https://doi.org/10.1017/S0144686X21000234 